\title{
The state of things: state history and theory reconfigured
}

\author{
Patrick Joyce $^{1} \cdot$ Chandra Mukerji $^{2}$
}

Published online: 3 May 2017

(C) The Author(s) 2017. This article is an open access publication

\begin{abstract}
This article looks at the relationship between logistical power and the assemblages of sites that constitute modern states. Rather than treating states as centralizing institutions and singular sites of power, we treat them as multi-sited. They gain power by using logistical methods of problem solving, using infrastructures to enforce and depersonalize relations of domination and limit the autonomy of elites. But states necessarily solve diverse problems by different means in multiple locations. So, educating children is not continuous with governing colonies even though both are necessary to nineteenth-century states. For this reason, states use logistical means of coordination to link sites, and they make the power of the state seem unitary even though the exercise of state power is not.
\end{abstract}

Keywords Assemblages $\cdot$ Bureaucracy $\cdot$ Infrastructure $\cdot$ Logistics $\cdot$ Materiality $\cdot$ Political culture

In spite of efforts to rethink the character of states and how they operate, most theories of the state still treat it as a unitary actor. But it is not. States are assemblages of the active agencies of many and often conflicting people and objects in a myriad of sites from prisons to schools, military bases and highways. They are held together, sometimes very uncertainly, at particular key sites and through the actions of key actors and processes, human and nonhuman Joyce (2013; Joyce and Bennett 2010). We therefore approach the state in terms of the material processes and practices it employs to explain its complex and emergent forms. The state is an assemblage that is distinguished as a

Patrick Joyce

patrick.joyce@manchester.ac.uk

Chandra Mukerji

cmukerji@gmail.com

1 Department of History, University of Manchester, Oxford Road, Manchester M13 9PL, UK

2 Department of Communication 0503, University of California, San Diego, 9500 Gilman Drive, La Jolla, CA 92093-0503, USA 
whole by its ability and tendency to use logistical power Mukerji (2010a, b) — a form of material practice that extends across its multiple sites. States employ logistical modes of political problem-solving as a means of exercising impersonal power, entering into many different domains of human activity in which issues of domination are at stake. To the extent that states are experiments in logistical power-which they invariably are - they develop new sites and material practices, responding to changing political circumstances. But they remain assemblages of depersonalized power as they use diverse forms of material practice to affect the playing field of power Mukerji (2011).

To make this argument, we analyze the different material processes used in state politics in France in the seventeenth century and Britain in the nineteenth century. In developing our analysis, we trace the emergence of state practices of logistical power, but we are concerned to avoid teleological and deterministic accounts of state materiality, such as those underlying James Scott's depiction of "modern" state power as a material outcome of centralized planning Scott $(1985,1998)$. The problem with Scott's approach, and it is apparent in De Certeau's work on resistances to power too, is that governmental techniques are construed as having a builtin essence expressing an inherent political coherence and logic that represents elite values or strategic interests De Certeau $(1984,1986)$. We argue instead that the distinguishing feature of the state is its impersonal and diffuse character that results from the turn to logistical power in its different domains. Exercising logistical power allows states to side-step the direct control of ruling elites, turning states into obligatory passage points for those wanting to exercise modern forms of power. To gain power, elites must go through state forms, forms that either severely restrict or negate their autonomy.

Coming from different directions as we do, a historian and a sociologist, and studying different moments in the history of states, we have tried to produce both an empirically grounded and theoretically precise account of logistical governance and state power. To this end, we talk explicitly and pointedly of a "state of things," a state that is heterogeneous, multiplex, and always in formation, not an entity seen in a priori terms, as in Weberian theory Weber et al. (1978). Nonetheless, we begin from the assertion in Weber's theory that modern states are impersonal. We identify the state's power in its nonhuman forms - from transport infrastructures to post offices to legal archives. These material formations of state power are distributed tools of governance and they often act independently of each other and even of officials. We argue not only that both humans and nonhumans help constitute states, but that the state exists in different configurations of people and things joined to exercise different kinds of logistical power.

This approach, however, might seem to make the state dissolve into an amorphous entity without coherence or direction. But the state is materially constructed to seem part of a whole and a singular form of agency even if it is actually not. The physical presence of states in territorial infrastructures, military weaponry, agency archives, and post offices give it a palpable presence and identifying features. Of course, other institutions also exercise logistical and impersonal power, including powers of a rational, rule-governed kind, great capitalist corporations for example. But what distinguishes the state - when it is not deeply weak - is that it has territorial, legal, and bureaucratic infrastructures unlike other institutions, and the logistical power it exerts affects political problem-solving. 
The state is extensive, diffuse, and experimental because it is always being pushed to change by political circumstances. State logistical power is both impersonal and material, and thus, it is particularly hard to articulate and thereby to criticize. The power of the state is mostly experienced outside discourse and below the level of conscious awareness, in the habitus, and the shared practices of life created by logistical governance. The state's material effects lend strongly to its naturalization, the perception of it as a single, overarching "thing." The inarticulacy of its sociomaterial power makes state practices serve as a context or a landscape in which political action takes place. Thus it is easy to reduce the state to its sites: post offices, law courts, legislatures, highway systems, etc.

There is no overarching historical logic to the state's development; rather it eventuates in and through the historical processes of its own experimental making, and out of the particular powers at work in this making. It is not omniscient but on the contrary frequently myopic, what Mukerji calls "unintended" Mukerji (2010a, b). This does not mean that it has no direction, for while the state emerges out of the play of historical circumstances, as in the example of the role of canal engineering in the French absolutist state Mukerji (2009), over time it builds up high levels of experience and expertise in the use of logistical power, the material practices giving state agents distinctive social characteristics. It becomes self-conscious, concerned to manufacture its own state effects through the conscious intervention of bureaucrats, experts of all sorts, and politicians. We agree with Timothy Mitchell's understanding of the state effect, namely the idea that the line between state and non-state is drawn in practice, but we suggest that over time the state itself sets down contexts of practice, especially through the physical practices of bureaucracies keen to delineate the boundaries of the state and produce state effects. ${ }^{1}$ Thus it is that we can use the impersonal pronoun regarding the state, while recognizing that it is not a unitary, internally coherent, actor, but rather, an on-going experiment in gathering and deploying logistical power.

Our argument is emphatically a historical one, looking at processes of exercising power, and their transformations over time. This is all the more so because we see the rise of logistical power and the emergence of modern sovereignty as coeval and deeply interrelated. The birth of the modern state - a state that is separable from the personal power of a king, emperor, religious potentate, and so on-was made possible by the investiture of sovereignty in territory. The territories assigned to states gave them legitimate logistical powers as well as spheres of operation. In this context, as Mukerji has written, the state comes of age with the turn to logistical power and the turn to techniques of impersonal rule Mukerji $(2010 \mathrm{a}, \mathrm{b})$. And we would add here that sovereignty, including its profoundly important components of majesty, magic, and the quasi-religious, is not foreign to logistical power. On the contrary the magic and majesty of state sovereignty are produced by logistical means, in the form of art programs, political rituals, law courts and legal documents, of palaces and parliaments, and much more.

To look at the consequences of the logistical turn for states in the seventeenth century, we look at Joyce's work on nineteenth-century liberal states. By comparison with the earlier period, there is an increased diffusion, consistency, and sophistication of the state's grasp of logistical power. The state produces new forms of logistical power,

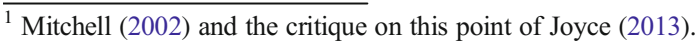


almost always getting an edge this way over other contenders for power (although recent times may be different). Standardization and forms of calculation, including state statistical programs, were added to the impersonal tool kit of states Porter (1997); Leibler (2005). When things can be more easily measured, they are made "objective" and abstract, and so more easily governed, at least in theory. Standards, systems, routines gave rise to new experiences of the state in the nineteenth century.

The next two sections below trace the change, one that we characterize as a transition from territory to communications. Central to this was the idea of the system. The liberal state's self-constitution and the state's increasing mastery of logistical power eventuated in the idea, if by no means always the reality, of the system as something that was seamless, stable, and secure, as well as a rational and efficient. And the state at the level of the habitus was experienced by its citizens as systematic, affecting many aspects of the citizen's whole life course. By the nineteenth century, as Joyce argues, the citizen's experience of these interlocking nodes of government with systematic but distinct properties created the idea of the state as itself a system, or at least system-like. So, while Mukerji's work helps us understand the systematic origins of state power in logistical terms, Joyce's work helps us see the state's development into a kind of social system - a source of experiments in logistical power enacted in multiple sites. In making this analysis, we share much with Foucault's understanding of power, something especially apparent in Joyce's work Joyce (2003). This sympathy is especially apparent in regard to the second wave of Foucault scholarship based on the thirteen volumes of the College de France lectures where Foucault directly approaches the question of the state. ${ }^{2}$ In particular, it is the co-emergence and mutual generation of state logistical power as we describe it and governmentality in the succeeding forms of the science of Polizeiwissenschaft and of Raison d'État, and then the emergence of liberal governmentality and "economy", that is so striking. The exercise of logistical power poses questions of knowledge as well as of practice that become important to states and adds a new layer of materiality of Foucault's analysis of them.

Here we would simply observe that as Mukerji writes, "For Foucault, the panopticon is a strategic instrument of power but how it is engineered does not matter: its power lies in its design." ${ }^{3}$ Traditions of construction do not enter into discussions of the panopticon, and the same is true for the skills of masons. We also argue for the autonomous agency of things in a way that while Foucault's concept of the dispositif is in many ways congenial to us its rootedness in discursivity we find limiting. The latter is apparent in the drift of his definition of the term as "a thoroughly heterogeneous ensemble consisting of discourses, institutions, architectural forms, regulatory decisions, laws, administrative measures, scientific statements, philosophical, moral and philanthropic propositions-in short, the said as much as the unsaid" Foucault (1980). Quite so, but we would argue, the done more than the said, or written.

This article is nonetheless in part an attempt to build on Foucault's approach to power by studying the material practices of states and by analyzing the social and political implications of logistical power. State power in our view is not only or mainly restricted to the power of law, social organization, political legitimacy, and ideas. It

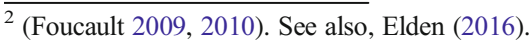

${ }^{3}$ Mukerji (2009), p. 216.
} 
involves the impersonal power of governance through things: legal documents that regulate conduct, the arsenals and soldiers formed to enact legitimate violence, and too the countless other things that shape the human and non-human environments that define the history and destiny of nations and states.

We ground our analysis not only in Foucault, but also in the material turn in theories of the state evident in the work of many scholars, including Timothy Mitchell, Ken Alder, Rick Biernacki, Karl Appuhn, Stephen Shapin, and many others. ${ }^{4}$ As Marx indicated, material conditions are foundations for social hierarchies, so material practices of political life affect social relations, exercising this kind of impersonal and indirect power, working through things to govern people, outside debate. But we rely on Mukerji's distinction between strategic and logistical power. ${ }^{5}$ She defines strategic power as interpersonal power, or the efforts by groups to dominate one another through threats of violence or control of languages of personal legitimacy. In contrast, logistical power is the use of material means to shape conditions of political possibility. Turning to logistics allowed states to break through patterns of patrimonial authority that had kept states weak and noble officials strong.

But our point here is not to reiterate the importance of logistics, but rather to demonstrate the variety of forms states adopted to gain logistical advantages in domains of power. We can see how the desire to exercise different types of logistical power helped to produce the distributed character of states described by Joyce as assemblages. Historical efforts to gain standing in different domains led to the cumulative multiplication over time of material means of exercising power and sites for doing this. Different forms of logistics were wielded in different parts of the state, making the power of the state hard to pin down but also creating problems of coordination within it. In principle, we could look at, among other things, weapons, property regimes, and industrial practices - all distinct forms of logistical control with different governmental bodies addressing them. So, the government has many faces and places in states, but state agents clearly depend on controlling logistical methods for assuring state power.

This means that states with their multiple and complex logistical infrastructures depend on Weberian "servants without standing" Weber et al. (1978) to engage in many of the ordinary practices of state power: fly fighter jets, teach in schools, sort mail, or run the national archive. These experts know how to get things done, and in creating and reshaping infrastructures of power, they limit what is politically possible. This means that states as institutions defined by their logistical power can never be reduced to simple expressions of elite interests, or strategic calculation. Elites must exercise power through the state rather than independently. The accumulation of various forms of logistical power makes the state an obligatory passage point in Callon's terms Callon (1986).

By looking at the investment by states in different forms of logistical power, we explain why states are necessarily distributed and heterogeneous in character. Their diverse forms derive from the multiple logistical methods used by state agents to gain

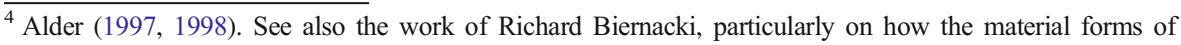
factories and of payment systems embedded different notions of human labor, in the process transmitting these over very long periods of historical time. Biernacki (1995); Becker and Clark (2001). Mitchell (2011); Appuhn (2009); Shapin (1994). See also Headrick (1998, 2010); Steinmetz (1999); Guldi (2012). We are also indebted to our students: Vernon (2007); Otter (2008); Carroll (2008).

${ }^{5}$ Mukerji (2009), ch. 2 and especially ch. 9, (Mukerji 2010a, b).
} 
power in their own administrative areas. States are assemblages of sites where logical solutions to problems are devised and implemented. Exercising logistical power in diverse ways allows states to address important and emerging fields of power. Still, their consistent use of material powers across sites gives states a distinctive quality, making them impersonal forms governance through which persons seeking power have to go.

Critics might argue that elevating logistical power over strategic power this way in explaining the character of states is misplaced because logistical and strategic power are necessarily mixed in politics, as elites use strategic means to affect logistical policies of the state. Who gets government contracts or is put in charge of foreign policy matters. We readily acknowledge this mixing of powers, but states could only become institutions of modern power by breaking with patrimonial traditions and using logistical means to evade the patrimonial powers of elites. In both the seventeenth and nineteenth centuries, there is strong evidence of administrators wielding material powers to become or remain dominant both over administrative bureaucracies and state territory. They produced less an apparatus of power than an impersonal, mute, diverse, and effective political habitus, one operating across an assemblage of sites and developed through distinct and distinguishing logistical practices of power.

So, we focus like Weber on state formation as a practice of depersonalizing power, but identify the shift in state power to material practices of depersonalization. Weber focused mainly on the social means of depersonalization in state bureaucracies and only hinted at the importance of material forms when he argued the importance of bureaucratic files. ${ }^{6}$ He overlooked the other logistical methods that states developed to make them institutionally more powerful. Only by recognizing these impersonal techniques can we understand state formation properly. The growth of state formation in Western Europe was not, as social theory has often suggested, the military control of states. Military power was only one form of logistical practice that states used to assert their power, only one of a number of methods of state territorial control. These territorial practices gave states a distinct set of powers that landholders could not match, and helped to tip the balance of power toward the emerging system of impersonal rule.

\section{State formation and territorial infrastructures in the seventeenth century}

Jean-Baptiste Colbert's administration, serving Louis XIV, was seminal in turning to logistical means to enhance state power. His administration systematically made territorial improvements in the name of the king, and built knowledge infrastructures, collections of historical legal documents and of books and papers as well as experts in their uses. These served to empower the state. Jacob Soll has described Louis XIV's minister, Colbert, as an information master, too Soll (2011). The collection of papers and books on law and legal precedents helped build a library that was in effect a practice of logistical politics that complemented and helped extend the territorial practices of administration by helping specify the legal bases of the state's power over its territory Mukerji (2010a, b; 2011). By locating legal documents from the period of Charlemagne, Colbert's librarian, Etienne Baluze, was able to write the Histore des

\footnotetext{
$\overline{{ }^{6} \text { Weber et al. (1978), pp. 956-999. }}$
} 
capitulaires des Rois François (Baluze 1677) that documented that the French Church had been subordinate to the Emperor Charlemagne in matters of politics and had illegally usurped political power in later periods. ${ }^{7}$

The use of logistical power by states was not new, but states gained an advantage in using logistics from the Peace of Augsburg of 1555 and Treaty of Westphalia of 1648. These were measures meant to bring an end to the Wars of Religion, not empower states. But the first established the principle of sovereignty and the second designated territories over which sovereigns ruled. The agreements in themselves did not empower states, but rather asserted their autonomy from one another and gave sovereigns the right to establish religious policy. Autonomy and personal rule were reinforced this way, shoring up the foundations of patrimonial power. But the assignment of territories to sovereigns gave them material powers that were not shared by the nobility or the church. This was the key change. Claims to lands and policies in governing those lands were distinct and provided the legal foundations for states to build territorial infrastructures as tools of impersonal rule. And principles of stewardship that were shared by Christians of all faiths justified the use of the earth for collective improvement and defined improvement as the duty of sovereigns. ${ }^{8}$

In this context, Colbert's administration began to explore logistical politics, the cultivation of material means to exercise impersonal power in the name of the king. The monarch was still assumed to exercise personal will, and projects of improvement like forest reform and infrastructural development were understood as expressions of royal will. It was the job of the sovereign to set policies and to be steward of state territory. But the type of power being exercised through things rather than patrimonial networks did not resemble the power of elites, and so could bypass the powers of those of rank. ${ }^{9}$

There were a number of projects of territorial improvement and logistical empowerment of the French state that were important to state formation. One was the construction of the Canal du Midi; another was the development of the Parisian water supply; and a third was the forest reform. All were made possible by the right and duty of the sovereign to improve the kingdom, and all increased the capacity of the state to dominate by materially shaping forms of collective life. The Canal du Midi was a project of infrastructural engineering designed to link the Atlantic to the Mediterranean. It was a navigational canal that started at the Garonne River in Toulouse and, after crossing the continental divide, reached the Mediterranean at the new port of Sète. It was a massive and technically complicated project that was considered by some as a wonder of the world on its completion. So, it was a showy display of good stewardship and infrastructural engineering deemed worthy of Rome. Most importantly, it changed the playing field of power in the southwest of France, a dissident region only tenuously loyal to the king. It changed land values and uses in significant ways, demonstrating the power of the state at the local level through mute and impersonal means. It also demonstrated what the state could do what individual landholders could not, encouraging nobles to go through agents of the state in seeking to assure their powers. ${ }^{10}$

\footnotetext{
$\overline{7}$ Soll (2011), pp. 102-103; Baluze (1677).

${ }^{8}$ Mukerji (2017a, b), chs. 2-3.

${ }^{9}$ Mukerji (2009), pp. 204-221.

${ }^{10}$ Mukerji (2009), particularly chs. 8-9.
} 
The Parisian water supply was first improved by Henri IV as a demonstrable work of good stewardship to legitimate his position of the throne. He had authorized the development of the Samaritaine Pump on the Pont Neuf in Paris that was used to pump water from the cleaner currents in the middle of the river to distribution points on the right bank of Paris. He died before a water supply was created for the left bank, but his widow, Catherine de Medici, saw that it was built. Water from nearby hills was carried by aqueduct to the Luxembourg Garden and Charity Hospital on the Left bank. $^{11}$

The problem that remained was distribution, and this was addressed under Louis XIV. He appointed Jean Beausire to design the distribution system that would create public fountains throughout Paris. This project helped Paris develop as a city of neighborhoods, and make it a place where common people were joined by material means to the state. Parisians still honored Henri IV as architect of the plan, but the elaboration of the system also helped to underscore the capacity of the state to improve the well-being and productivity of Parisians through acts of good stewardship and impersonal rule. ${ }^{12}$

Colbert's forest reform was another territorial project that increased the state's capacity to protect trees useful to ship building by studying and regulating forests. In this case, a project of territorial management produced legal archives and created an administrative means of regulating the use of forests. Knowledge and territory, while different forms of logistical power, were also closely linked. The project was less successful in protecting French forests than it was in transferring information to the state that allowed the administration to hold people accountable for their uses of timber and timber reserves. It was a regulatory tool that was justified by principles of sovereignty and stewardship, but it was most importantly an impersonal means for placing state officials between landholders and the forests they managed. Nobles were already forestry officials as estate holders, but they treated their lands as their own domains, and they were supervised in principle by courts on which they often served as justices. The forest reform set up new courts in which forestry officials had less power, and held people accountable for timbering that now could be documented in relation to the surveys made by Colbert's forestry experts. Using old maps and testimony, landholders were also held accountable for old abuses, using the knowledge infrastructure of old maps, land rights documents, new surveys, and testimony taken down by forestry officials on rights, claims, and abuses. The result was an information infrastructure that made forestry less a matter of personal will and more a matter of impersonal measures and judgment Mukerji (2011).

Karl Appuhn's work on the Venetian Republic similarly shows how territorial and knowledge infrastructures were necessarily co-constitutive, creating dual sites and practices of power Appuhn (2009). Venice needed timber to maintain its seaborne empire - mainly for ship building and the infrastructure of canals - and so leaders began to acquire and manage territory with forests. Managing these natural resources and making ship timber available to the arsenal led to surveys of forests and archives of the resulting documents. Making forests into a territorial resource was connected to making archives, but it created different sites and practices of government. Those who

\footnotetext{
${ }^{11}$ Mukerji (2017a, b), ch. 2.

${ }^{12}$ Mukerji (2017a, b), ch. 2.
} 
inspected and cared for trees went into various areas of the countryside to assess the forests and to govern their uses. They brought back data that could be studied independently in Venice, far from the trees and deep in the archives. Territorial governance of timber reserves in multiple forests required the accumulation and circulation of knowledge, and this led to the formation of bureaucratic processes of using paperwork. Both types of logistical power were necessary parts of empowering the Venetian state. So, the pattern in seventeenth-century France was comparable to what happened elsewhere. Efforts to gain greater control of territory and put it more effectively to political use yielded multiple yet increasingly related sites and types of logistical power. The power of the state was visible in the countryside in political uses of natural resources and forces, and it was visible in the formation of archives in cities where knowledge infrastructures were used to control the patrimonial patterns of elites, and the legal bases of elite power.

\section{From territory to communications: the British state in the nineteenth century}

Joyce has shown that during the nineteenth century paperwork ("file engineering" as he calls it) was used to reconfigure the nineteenth-century state as a purveyor and instantiation of liberal values. As an imperial state that was territorially diffuse, territorial sovereignty was still problematic for the British, but the control of colonial and domestic lands could be presumed. So files were more important than ever as links among groups and sites of knowledge control.

The case of the British nineteenth- and twentieth-century imperial state was both similar to and different from that of France. The expansion of the state across multiple territories was already accomplished so the biggest problem of a state with lots of sites and exercising so many forms of logistical practices was the consolidation of information systems to link highly disparate places and people to a new logic of power. This posed problems of communication that made the impersonal tools of officialdom more vital and hard to trace, including that part of it involved in colonial administration.. ${ }^{13}$ The everyday operations of running the empire, and in the process shaping imperial and British identities, were constructed on the ground and in the flow of things.

For example, at the India Office, responsible for governing India after 1857, archives were ways to document territorial practices and then to link social actors across places, across the empire at large but also within institutions like the government office itself. They were social products of the distributed work of many authors, arranged in many forms and layers of interlinked agency, including the middle and lower levels of bureaucratic hierarchies themselves. They became important tools for negotiating power across sites, and making them more systematic in operation.

Becoming an "information master" was now clearly a route to power. Much of governing the British state and empire was a very difficult balancing act, permitting initiative and expertise from below while ensuring that power and direction remained with the upper levels. The upper administration depended on those lower down the chain of the hierarchy, particularly the initiative of clerks in finding as well as writing

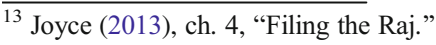


documents. Familiarity with the files meant that staff often knew where to find documents even if systems let them down. The individual bureaucrat could therefore impose his personality on the "system" despite the rituals of address, the formulaic nature of reporting information, and so on. Lower level civil servants continued to express their own opinions and to bring all sorts of baggage with them to their jobs. ${ }^{14}$ This is one illustration of how personal power, at however humble a level, still operated within the context of impersonal tools of logistical rule.

Administration in this view becomes a mode of political practice or governance more than an institutional form. It depended upon logistical practices of "connectivity," and above all the proliferation of artifacts to do the connecting, namely signs, in the shape of words and numbers-now considered in their materialities not just their semantics. ${ }^{15}$ Administration was less a matter of creating centers of calculation than moving information between different sites and linking different modes of governance. In the process, to use Latour's term, "immutable mobiles" like bureaucratic files helped to bring into political relations mutable immobiles like land. ${ }^{16}$ Land was engineered to create a new political habitus, using its mutability to change the conditions of social possibility for political effect, while files circulated to enroll social actors in these political practices. The result was the creation of networks and systems in the state rather than a singular social apparatus. Natural forces, paperwork, communication, bureaucracy, and education were all used in laying down the material foundations of power, aiding in its communication, providing means for its control, and furthering its reproduction.

Joyce's work on the Raj is particularly useful for understanding the material practices of administration and how they work to enhance and stabilize power, but can also have contradictory effects. The British Empire was thus at once a powerful but unstable structure of power. The systemic qualities of centers of connection were dysfunctional as well as functional. (This is one of the major ironies of all government.) Sources of instability were a constant in the late nineteenth century. The increasing volume of paper communication was forever threatening to overwhelm existing arrangements (this deluge was in British India dubbed "the monster of Correspondence" by Viceroy Curzon). ${ }^{17}$ As new systems were put in place to handle problems of managing paperwork, they invariably ran up against the limits of the very changes they had instituted or these changes were productive of unforeseen outcomes that generated more complexity and incoherence.

One very good example of this was the shift from the old folded system of papers around the 1880s. This shows how what on the surface looks like a tiny change can in the domain of logistical power frequently have huge consequences. The new open file system changed the age-old procedure whereby an incoming letter itself formed the file on its subject, being folded into four so that the blank front of the letter became the place on which the docket and minute were written. The inconvenience of this system was immense, for it involved the doubling and sometimes the quadrupling up of papers

\footnotetext{
${ }^{14}$ As well as chap. 4 on "Filing the Raj," see Becker and Von Krosigk (2008); Feldman (2008); Messick (1993); Stoler (2010); Ogborn (2007).

15 Joyce, The State of Freedom where "connectivity" is considered in numerous settings, from postal to administrative systems, but also in terms of elite education (another sort of connecting). See also Otis (2001).

${ }^{16}$ Callon (1998); Latour (1987, 1999, 2005).

${ }^{17}$ On Curzon, State of Freedom, pp. 150-151, 164, 225.
} 
(then placed in shells or jackets), there being constant complaints about the crowding of the available space for writing, much of which was illegible. If correspondence was not itself used for noting, then small notebooks were placed in the four-folded papers, an even more inconvenient system. All this put a premium on the "inside knowledge" of those lower down in the bureaucratic hierarchy.

This system was only abandoned in India in the 1880s. Papers and letters could now be attached as they were received, one after the other, heading them with a table of contents, and noting upon them freely. In the instance of the Home Office only in 1885 did new papers begin to be put away flat in white jackets, the front of which formed the first minute, to which extra sheets could be added. This practice gradually led throughout the office to "a modern, organized system" of writing minutes: the illegible scrawls that had frequently been unsigned and undated became neater, more expansive, and more clearly initialed and dated. The personal power of the clerk was controlled.

However, in typically contradictory fashion, precisely because the whole sheet of paper now became available for comment and notes, and because file contents became much more accessible and more easily itemized, there was an unexpected and almost uncontrollable increase in the amount of writing in India. Confusion was compounded by the surprisingly late development (during the period 1900-1914) of the horizontal systems of filing that we take so much for granted today. This was a true landmark in this micro-world of file engineering; what seems glaringly self-evident to later generations - you file horizontally not vertically — was the product of conscious discovery and imagination. $^{18}$

Another revealing instance of the paradoxes accompanying the deepening systematic quality of paperwork involved printing: on the face of it the development of printing rather than handwriting documents would seem straightforwardly a case of bureaucratic advance. In some respects, especially in Britain, increasingly cheap printing was a boon, but in India its relatively minute costs, reflected in the printing of even the obscure remarks of lowly clerks, led to a profusion of documented material that again fed the monster of correspondence and allowed for lower level initiative and influence. Out of paradoxes and contradictions such as this was forged the qualified stability that we call the imperial state.

While the material tools of administration, both archiving and communicating, were more elaborate in the nineteenth century, they were also important to the French state and Venetian Republic, as we saw earlier. Controlling territories entailed keeping and circulating public records. And so the material practices of administration that Joyce documents not only help to describe the British state and its techniques of empire, but also establish the centrality of materiality in administration as a defining practice of modern states.

\section{State imaginaries}

On a bigger stage, states also used logistical means to project a sense of coherence and direction, building cultural imaginaries about the future to turn political goals into ways of life. As much as states need modes of social coordination, they also depend on

${ }^{18}$ Ibid., pp. 174-176, and on registration and cataloguing, pp. 176-184. 
cultural modes of imagination - not only the imagined communities of Benedict Anderson, but also imagined histories and destinies that seem real because they are visible in the design of things and lived out in and through the them in everyday life Anderson (2006); Rafael (2000); Hall (1997); Mukerji (2016). Political identities are forged with government buildings, infrastructures like roads, canals, and urban amenities, and public spaces and objects, like parks and public artwork. How they are designed is important to how politics is imagined Dobbin (1994). The material construction of modern states creates a cultural context for social worlds of action that make cultural imaginaries seem real by making them real in their consequences.

The political effectiveness of these programs is illustrated particularly well in the history of the French state. Mukerji has shown how art and architecture under Louis XIV were used to imagine the French state as the carrier of the classical tradition and as heir to the imperial legacy of Rome. Mukerji uses figured world theory to expand upon Foucault's ideas about the Panopticon by explaining how people can learn from the symbolic and material spaces they inhabit. In shaping environments, states create spaces that project dreams of order and power animating state governance. In France, the dream was of Roman revival, and it was embedded in the art and architecture of the regime. Enacting roles within the dream world of Roman revival forced nobles to inhabit these political logics and entertain them as real. They are not forced to learn the lessons, per se, but in a controlled space like Versailles where courtiers lived, the lessons embedded in the chateau and park were hard to escape Mukerji (2012).

With characteristic brilliance Foucault pointed to the connections between the organization of the court of Louis XIV and the entrenchment of state power. As he wrote, "Just as in politics, raison d'État manifests itself in a kind of theatricality, so theatre is organized around the representation of this raison d'État in its dramatic, intense and violent forms of the coup d'État. We could say that the court, as organized by Louis XIV, is precisely the point of articulation, the place where raison d'État is dramatized in the form of intrigues, disgraces, preferences, exclusions, and exiles and also the place, precisely, where theatre represents the state itself."

But the theatricality at Versailles did not just embody the power of the state and its purposes. It was a means of transforming the nobility by seducing them with dreams of imperial history and destiny. Mukerji argues that the architecture, art, and classical stories that were performed for different parties in the park of Versailles served as "props" or "scaffolding" for dreaming about a French military empire like that of Rome. The activities seemed innocent enough, but had radical political effects. Dreams of Rome stood as a secular contrast to the older, sacred political imaginary underlying patrimonial politics, and the dreams of imperial glory made the rejection of traditional aspirations seem worthwhile for the nobles of the sword. The baroque and neo-classical art developed under Louis XIV had semiotic ties to the ancient world and silently contributed to a political culture emphasizing military prowess, legal documentation/ archiving, infrastructural development using natural knowledge, and mathematical precision in thought and design. The verbal equation of France with Rome was revolutionarily modernizing, so it was not so easy to promote. Verbal assertions about France as heir to Roman greatness and descriptions of Louis XIV as a new emperor failed, but neo-classical architecture did not. Buildings indexing Rome semiotically made France more like the ancient empire and seem more likely to carry its mantle. The capacity to demonstrate material practices like those of Rome was quite different from 
representing the king as Apollo or Hercules. As Peter Burke points out, it was easy for critics to argue that Louis XIV was no Augustus, but as Mukerji has shown, it was harder to discount a triumphal arch in Paris. Architectural formations such as triumphal arches created semiotic chains, connecting ancient Gaul, classical Rome, and France of the seventeenth century Mukerji $(2017 \mathrm{a}, \mathrm{b})$.

Figured world theory, as a cultural theory of learning, helps explain how the new political imaginary could be taught through things. And understanding the revolutionary character of dreams of Rome in French politics helps explain the meteoric rise in state power under Louis XIV. France had become a weak state dominated by the clergy under Richelieu and Mazarin, and run by noble officials with independent powers alienated from the crown. But within twenty five years under Louis XIV the state became such a powerful one that it was called absolutist. The court did not starve nobles of their riches, as Elias asserted (Elias et al. 2006). And although Colbert worked on gaining power for the king through economic policies, the revocation of the Edict of Nantes destroyed the economy as Huguenots fled to England, the Netherlands and Switzerland. The French military was also not the cause of this change. The military was never fully taken from noble control, nor was it able to expand French territory to serve Louis XIV's dreams of empire. What changed in this regime was the cultural program that used material means to equate France with Rome.

As Mukerji has shown, the administration used territorial infrastructure to loosen noble control of land, and as Soll has demonstrated, Colbert used legal archives to revive precedents from the Holy Roman Empire to empower the state. Surprisingly, the administration patronized academies and artisans at the Louvre to build dream worlds of classical revival at Versailles and in Paris. The dreams of Rome legitimated territorial practices, also the use of legal precedents from Rome, and set out a more worldly logic of power. In other words, the ancient world was used to construct by logistical means a modern dream of power Mukerji (2012, 2017a, b).

In liberal Britain, state imaginaries took a different form than in France, emphasizing liberal freedom. Joyce has considered the role of communications in doing this work through the British Post Office. If people in the liberal state were to be "freed" in the realms of the market this was also so in civil society. Yet the "freeing" of these zones was accompanied by the invention of a whole series of attempts to shape and manage conduct within them in desirable ways. On the one hand, the public activities of free citizens were to be regulated by codes of civility, reason and orderliness. On the other, the private conduct of these citizens was to be civilized by equipping them with languages and techniques of self-understanding and self-mastery. As well as being one of the agents that facilitated commerce and industry, the Post Office was therefore also involved in the creation of the kind of subjects capable of existing and acting freely. The most crucial aspect of this was the ability to cultivate ethical subjects capable of self-subjection. The act of letter writing was itself an important aspect of this cultivation of self and external awareness. Among other technologies the governance of the letter was a means through which the liberal state imaginary was constructed.

One of the particular features of the Post Office was the way it acted to extend the connections among the state, its land, and the citizens, establishing its presence in every town and most villages in the country, embedding itself thoroughly in the practice of daily life. As connections were established over greater distance, the state and its 
systems of communication became essential to more and more of the citizen's life. The state and its communications' infrastructure were engineered into the lives of the citizens to the extent that much of the life of the nation came to depend upon the state's services. The transition from impermanent postal connectedness to permanent connectedness was of great significance in this regard. It meant that the network was always available and ever-present, in the sense that postal communications are always open for use, even if in practice their use may be limited. The correspondent is in theory always accessible, even if the letter is not written. The routes, links, and stations of the network are always there.

This is in contradistinction to the sending of individual utterances by a messenger or to delivery that depended on the vagaries of personal inquiry, as in the pay-on-receipt system before the postal reforms of the mid-nineteenth century. In the transition from impermanent postal connectedness to permanent connectedness it was the development of addressability that mattered. Addressability meant that one was now inevitably part of a new system of connection, like it or not (and in the early days there were many who did not like this at all, hating to be ever available to the letter carrier). In this sense therefore, as the network became increasingly systematic it took on the shape of both an actual and an imagined system. The postal network was therefore one element of the liberal state imaginary, "the postal state" increasingly looming large over contemporary life as a strange kind of entity, invisible and abstract on the one hand, but real and concrete at the same time.

Permanent connectedness could now be more fully "taught" and learned. What evolved was a technology of trust in the state produced by human and machine-made predictability and reliability. Trust was performed in action, in use, the action of trusting in the use of the postbox for example, a receptacle often lone and isolated, and seemingly unprotected from theft and vandalism. The actual use of the system, its material embodiment in human practice, performed the state. Embedded in things and practices - in offices themselves, in uniforms - the post system became in time the object of a certain veneration, as something inherently British, efficient, unobtrusive, and yet dependable, the ideal vehicle to represent the rights and liberties of the freeborn British letter writer. ${ }^{19}$

However, in performing the state in the nineteenth century, people also performed "society" and thus the separation of the two entities, unlike earlier states such as that in France. "Society" was partly formatted by the state, as in people's understanding something distinct from the state and, like the economy, a "naturally" occurring reality. This reality was the very sphere they were now enabled as citizens to operate in, part of a "free" liberal society, that part made possible by the free communication of information they could now enter into thanks to the Post Office. This political ledgermain depended not only on the state's projection of distance between state and society, but precisely the opposite in many ways, namely the reiteration of presence, but of presence in the British case as something restrained and conditional, dependable and firm. Something that was present but not overwhelming, illiberal, and arbitrary. In short, the liberal state as a benign form of the liberal state imaginary (there were of course less benign forms).

\footnotetext{
${ }^{19}$ For a full treatment, Joyce (2013), pp. 53-144. See also Hadley (2010); Joyce (1993). For a culturalist reading of the British state, Corrigan and Sayer (1985).
} 
Thus it is that in both cases, political imaginaries were embedded in things. This allowed material manifestations of the state to teach political aspirations and logics, and most of the time these operated below the level of conscious awareness. At other times they gave symbolic content, all too evident to people's awareness, to state imaginaries. And while they brought coherence to the state, most states were and are fissiparous and complex. The coherence they brought was always qualified and conditional. In the liberal state disciplinary freedoms might be taken at face value and turned back upon the state. Nonetheless, the success and power of state imaginaries is apparent also, as is the success of the absolutist French state.

\section{Conclusion}

Reimagining the state not as a thing but as a shape-shifting assemblage of people and things allows us to understand state power differently. Rather than having the power of a totalizing system, a single bureaucratic embodiment of social rationality from which there is no escape, the state as we see it is powerful because it is multi-sited, material, and technical. We call attention to the impersonal powers of the state, but are mindful of the personal ones too. Being like this, the state is adaptable. It has many faces and forms so it is hard to identify and therefore hard to shape, whether the aim is to support or oppose it. People can object to policies or want to shrink government, but they want roads and functioning sewer and garbage collection systems. Even if they do not like what they perceive as the state system overall they want the things it brings and indeed take these for granted. Moreover, the state continually changes as new demands are made on it, for example making Internet access available in rural areas, or supporting wind farms or solar energy. It exists in subsidies to companies in some places as well as wires and generators in other places.

The materiality of the state depersonalizes power far more than bureaucratization. Even faceless bureaucrats are more personable than computers, canals, roads, and sewers. And it makes little sense to blow up a sewer because you hate the government if you live where that sewer operates. So, the state becomes complicitous in everyday life through things. The power of habits turns into the powers of the state.

It is also the case that the state has no core or center because it is at heart a communication complex and territorial entity, one that keeps reweaving the fabric of government with changing lines of communication and different ways of managing problems of distance. This gives the state power over information and its flows, implementing as it does an internal process of negotiation, struggle, and sharing that helps produce the flexibility and durability of the state. It may be hard to say what the state is because it is territorially extended and diverse, but it is even harder to say what the state does because much of what it does is acquire and move information through things.

However, we do not replace one totalization of the state by another, recognizing as we do the contingency of state forms, and the centrality of practice in logistical power. The state is realized in use, as it were, as it eventuates historically, different forms of the state coming into being not through some preordained plan but by means of the interactions (and so frequent contradictions) of different individuals, groups, technical processes, material objects, and so on. To extend the metaphor we earlier used, what 
matters is not the design but the engineering of the state, engineering frequently not being an exact science, and sometimes indeed "impossible." Not only is the state historically contingent but it is also vulnerable and unstable. When things fall apart the center cannot hold or at least is hard put to it. Pipes may leak, roads collapse, information in wires goes missing. Things, including humans, have in their operation unexpected consequences, and the new solutions created for these consequences in turn produce more problems.

In turn, personal and impersonal power may gel but also contradict one another, as in the case of seventeenth-century France where the proto-technocrat and the king's agents as different human modalities of power collided. Personal power may mobilize the technosocial in its own defense, as Mukerji shows for French royal governance and Joyce for the new emerging forms of a "professional" civil service in nineteenthcentury Britain. These modalities of state power are as impersonal as the paperwork that is pushed, connecting agency to the Lebensfuhrungen, ethical styles of life, that Weber wrote about and Foucault was so interested in. These styles of life are themselves impersonal, shaped by the logistical turn in state power. But the veil of secrecy that keeps state information flows mainly out of public view helps mask the return of personal power by officials, operating at particular times, using logistical practices of marking things secret at various levels. In the case of the nineteenth-century British high civil service, the code of "honorable secrecy," maintained by a whole new technology of "administration," reasserted aristocratic, part-patrimonial, powers within government and the often highly dishonorable exchanges of information and favors by which political work gets done by state agents Vincent (1998).

The strength of the state is therefore often bought at the price of dispersed power and muddled intentions and practices. It is not the all-seeing Leviathan it is sometimes taken to be. And, as part of the manifold assemblages that hold the state together human agency comes powerfully into the picture, not however in our account as solely or even mainly as intentional action, but nonetheless as actions reproduced and directed by humans, but now in the habitus, as part of the carrying on of daily life. In this sense what holds the state together are the cultural imaginaries we hold of it. The state has grown to embrace so much of our existence that our daily life is inconceivable without it. This is not simply a matter of health, security, education, and welfare, but "the state" regulates the air we breathe, the water we drink, the roads we walk on, the houses we live in, and much of what we do in our supposedly "private" houses. So, it is easy to believe it to be omnipresent and totalizing in spite of the fact that it is encountered in so many different sites and ways.

Today, "neoliberals" work to reduce the penetration of the state into society, aiming to reverse the growth of the state, but they have also furthered the depersonalization of power. ${ }^{20}$ Neoliberalism depends on technocratic expertise in cutting state programs and building the GDP. So, neoliberalism has led to a new configuration of logistical power,

\footnotetext{
${ }^{20}$ For instance, by general consent rational choice theory is taken as one of the components of neoliberalism. The game theory at the heart of rational choice theory is what has made the neoliberal vision realizable. It supplies the micro-economic analysis that renders both individual and collective action intelligible. The valuation of persons in neoliberal technologies of governance defies the recognition of the juridical subject, where people are the possessors of rights. In neoliberalism, rational individuals engage in coercive bargaining, so that the intrinsic meaning of acts is displaced by performance indicators. The panoptic gaze of authority is no longer legitimated nor internalized. See e.g., S. M. Amadae (2003).
} 
not the "end" of the state as often claimed, a new adaptation of the state to changing political landscapes. Power now detours doubly around an active subject, not only filling government offices with faceless "servants without standing," but subordinating citizens to security and fiscal imperatives defined by state technocrats, once again using logistical power to dominate people through things.

Acknowledgements Chandra Mukerji would like to thank The Center for Advanced Study in the Behavioral Sciences and the University of California Humanities Research Institute for supporting portions of the research used in this article. Patrick Joyce would like to thank the members of the group he co-runs with Colin Gordon at the LSE and the Institute of Historical Research, University of London. The group is called "Foucault, political life and history".

Open Access This article is distributed under the terms of the Creative Commons Attribution 4.0 International License (http://creativecommons.org/licenses/by/4.0/), which permits unrestricted use, distribution, and reproduction in any medium, provided you give appropriate credit to the original author(s) and the source, provide a link to the Creative Commons license, and indicate if changes were made.

\section{References}

Alder, K. (1997). Engineering the Revolution: Arms and Enlightenment in France, 1763-1815. Princeton: Princeton University Press.

Alder, K. (1998). Making Things the Same: Representation, Tolerance and the end of the Ancien Regime in France. Social Studies of Science, 28, 4.

Amadae, S. M. (2003). Rationalising Democracy: the Cold War Origins of Rational Choice Liberalism. Chicago: University of Chicago Press.

Anderson, B. (2006). Imagined Communities: Reflections on the Origins and Spread of Nationalism. New York: Verso.

Appuhn, K. (2009). A Forest on the Sea: Environmental Expertise in Renaissance Venice. Baltimore: Johns Hopkins University Press.

Baluze, E. (1677). Histoire des Capitulaires des Rois François (p. 1755). Paris: La Hayte.

Becker, P., \& Clark, W. (Eds.). (2001). Little Tools of Knowledge: Historical Essays on Academic and Bureaucratic Practices. Ann Arbor: University of Michigan Press.

Becker, P., \& Von Krosigk, R. (Eds.). (2008). Figures of Authority: Contributions Towards a Cultural History of Governance from the Seventeenth to the Twentieth Century. Peter Laing: Brussels.

Biernacki, R. (1995). The Fabrication of Labor: Germany and Britain, 1640-1914. Oakland: California University Press.

Callon, M. (1986). Elements of a sociology of translation: Domestication of the Scallops and the Fishermen of St. Brieuc Bay. In J. Law (Ed.), Power, Action and Belief: A New Sociology of Knowledge? (pp. 196-233). London: Routledge.

Callon, M. (Ed.). (1998). The Laws of the Markets. London: Blackwell.

Carroll, P. (2008). Science, Culture and Modern State Formation. Oakland: University of California Press.

Corrigan, P., \& Sayer, D. (1985). The Great Arch; English State Formation as Cultural Revolution. Oxford: Basil Blackwell.

De Certeau, M. (1984). The Practice of Everyday Life. Oakland: University of California Press.

De Certeau, M. (1986). Heterologies: Discourse on the Other. Minneapolis: University of Minnesota Press.

Dobbin, F. (1994). Forging Industrial Policy: The United States, Britain, and France in the Railway Age. Cambridge: Cambridge University Press.

Elden, S. (2016). Foucault's Last Decade. Cambridge: Polity.

Elias, N., et al. (2006). Court Society. Dublin: University of Dublin Press.

Feldman, I. (2008). Governing Gaza: Bureaucracy, Authority and the Work of Rule, 1917-1967. Durham: Duke University Press.

Foucault, M. (1980). "The Confession of the Flesh" interview in Power/Knowledge Selected Interviews and Other Writings, ed. Colin Gordon. New York and London: Pantheon.

Foucault, M. (2009). Security, Territory, Population, Lectures at the College de France 1977-1978, ed. Michel Senellart, Palgrave. 
Foucault, M. (2010). The Birth of Biopolitics, Lectures at the College de France 1978-1979, ed. Michel Senellart. London: Palgrave.

Guldi, J. E. (2012). Roads to Power: Britain Invents the Infrastructure State. Cambridge: Harvard University Press.

Hadley, E. (2010). Living Liberalism: Practical Citizenship in Mid-Victorian Britain. Chicago: University of Chicago Press.

Hall, S. (1997). Representation. London: Sage.

Headrick, D. R. (1998). The Tentacles of Progress: Technological Transfer in the Age of Improvement, 18501940. Oxford: Oxford University Press.

Headrick, D. (2010). Power over Peoples: Technology, Environments, and Western Imperialism, 1400 to the Present. Princeton: Princeton University Press.

Joyce, P. (1993). Democratic Subjects: the Self and the Social in Nineteenth-Century England. Cambridge: Cambridge University Press.

Joyce, P. (2003). The Rule of Freedom: Liberalism and the Modern City. London: Verso.

Joyce, P. (2013). The State of Freedom: a Social History of the British State since 1800 (pp. 1-27). Cambridge: Cambridge University Press.

Joyce, P., \& Bennett, T. (Eds.). (2010). Material Powers: Cultural Studies, history and the Material Turn. London: Routledge.

Latour, B. (1987). Science in Action: How to Follow Scientists and Engineers through Society. Cambridge: Harvard University Press.

Latour, B. (1999). Pandora's Hope: Essays on the Reality of Science Studies. Cambridge: Harvard University Press.

Latour, B. (2005). Reassembling the Social: an Introduction to Actor-Network-Theory. Oxford: Oxford University Press.

Leibler, A. (2005). The Uncounted: Citizenship and Exclusion in the Israeli Census of 1948. Ethnic and Racial Studies, 28(5), 880-902.

Messick, B. (1993). The Calligraphic State: Textual Domination and History in a Muslim Society. Oakland: University of California Press.

Mitchell, T. (2002). The Rule of Experts: Egypt, Techno-Politics, Modernity. Oakland: University of California Press.

Mitchell, T. (2011). Carbon Democracy: Political Power in the Age of Oil. London: Verso.

Mukerji, C. (2009). Impossible Engineering: Technology and Territoriality on the Canal du Midi. Princeton: Princeton University Press.

Mukerji, C. (2010a). The Unintended State. In P. Joyce \& T. Bennett (Eds.), Material Powers: Cultural Studies, History and the Material Turn. London: Routledge.

Mukerji, C. (2010b). The Territorial State as a Figured World of Power: Strategics, Logistics, and Impersonal Rule. Sociological Theory, 28(4), 402-424.

Mukerji, C. (2011). Jurisdiction, inscription, and state formation, administrative modernism and knowledge regimes. Theory and Society, 40(3), 232-233.

Mukerji, C. (2012). Space and Political Pedagogy at the Gardens of Versailles. Public Culture, 24(3), 515-540.

Mukerji, C. (2016). Reimagining Modernity, forthcoming.

Mukerji, C. (2017a). Modernity Reimagined. New York and London: Taylor and Francis/Routledge.

Mukerji, C. (2017b). Artisans and the Construction of the French State: The Political Role of the Louvre's Workshops. in National Matters: Materiality, Culture, and Nationalism, by Geneviève Zubrzycki. Stanford: Stanford University Press.

Ogborn, M. (2007). Indian Ink: Script and Print in the Making of the East India Company. Chicago: University of Chicago Press.

Otis, L. (2001). Networking: Communicating With Bodies and Machines in the Nineteenth Century. Ann Arbor: University of Michigan Press.

Otter, C. (2008). The Victorian Eye: A Political History of Light and Vision in Britain, 1800-1910. Chicago: University of Chicago Press.

Porter, T. (1997). Trust in Numbers. Princeton: Princeton University Press.

Rafael, V. (2000). White Love and Other Events in Filipino History. Durham: Duke University Press.

Scott, J. (1985). Weapons of the Weak: Everyday Forms of Peasant Resistance. New Haven: Yale University Press.

Scott, J. (1998). Seeing Like a State: How Certain Schemes to Improve the Human Condition Have Failed. New Haven: Yale University Press. 
Shapin, S. (1994). A Social History of Truth: Civility and Science in Seventeenth-Century England. Chicago: University of Chicago Press.

Soll, J. (2011). The Information Master: Jean-Baptiste Colbert's Secret State Intelligence System. Ann Arbor: University of Michigan Press.

Steinmetz, G. (1999). State/Culture: State Formation after the Cultural Turn. Ithaca: Cornell University Press. Stoler, A. (2010). Along the Archival Grain: Epistemic Anxieties and Colonial Common Sense. Princeton: Princeton University Press.

Vernon, J. (2007). Hunger; A Modern History. Cambridge: Harvard University Press.

Vincent, D. (1998). The Culture of Secrecy: Britain 1832-1998. Oxford: Oxford University Press.

Weber, M., Roth, G., \& Wittich, C. (1978). Economy and Society (pp. 956-998). Berkeley: University of California Press.

Patrick Joyce is a distinguished social historian of Britain, who has always worked closely with the social sciences. His methodological interests have meant that his work has been received outside Britain and outside the history discipline alone. He is Emeritus Professor of History at Manchester University, and Honorary Professor of History, University of Edinburgh. Among his recent books are The state of freedom (Cambridge University Press 2013); Material powers (editor) (Routledge 2010); and The rule of freedom (Verso 2003).

Chandra Mukerji is Distinguished Professor Emerita of Communication and Science Studies at the University of California San Diego and Chercheuse Correspondante, Institut Marcel Mauss, Paris. She was co-Recipient of the Distinguished Book Award from the American Sociological Association 2012 for Impossible Engineering, won the Mary Douglas Prize in 1998 from the Sociology of Culture section of the ASA for Territorial Ambitions and the Gardens of Versailles; and was co-recipient of the Robert K. Merton Award from the SKAT section of the ASA in 1991 for A Fragile Power. She also published with M. Schudson, Rethinking Popular Culture (University of California Press, 1990), and her first book was From Graven Images: Patterns of Modern Materialism (Columbia University Press, 1983). Her newest book is Reimagining Modernity (Taylor and Francis/Routledge 2017). 